\title{
Chapter 5 \\ A Tale of Two Cities: Is Overvaluation a Capital Issue?
}

\author{
John Muellbauer
}

\section{Introduction}

Since the global financial crisis, there has been a great deal of research on links between credit growth, especially if real-estate linked, the overvaluation of house prices and financial stability. Cerutti et al. (2017), analysing an (unbalanced) panel data set of 50 countries for 1970-2012 find that house-price booms are more likely in countries with higher loan-to-value ratios and mortgage funding models based on securitization or wholesale sources. They find that most house-price booms end with a recession, and that such downturns are predicted to be deeper and longer when preceded by booms in both residential mortgages and other private debt, and in reliance on non-retail deposit funding that fuel duration mismatch problems on lenders' balance sheets. Muellbauer (2012) considered links between house price overvaluations and financial instability and suggested ways in which empirical evidence could be used to detect episodes of overvaluation. Muellbauer (2018a) spelled out further the amplifying and sometimes stabilising feedback loops in real

\footnotetext{
Paper prepared for the DNB conference Hot Property: the Housing Market in Major Cities, May 24-25, 2018 Amsterdam. Part of this paper builds on a research project pursued at the ECB during John Muellbauer's tenure of a Wim Duisenberg Visiting Fellowship, and in particular on a paper co-authored with Valerie Chauvin of Banque de France. Thanks are due for advice on French data from Guillaume Chapelle, Jacques Friggit, Andrew Goodwin and Clara Wolf, to James Wyatt on prime central London house prices, and to John Duca for helpful discussions. Longer term research support from the Open Society Foundation via INET at the Oxford Martin School is gratefully acknowledged.
}

J. Muellbauer $(\triangle)$

Nuffield College, Oxford, UK

Institute for New Economic Thinking at the Oxford Martin School, University of Oxford, Oxford, UK

e-mail: john.muellbauer@nuffield.ox.ac.uk

R. Nijskens et al. (eds.), Hot Property, https://doi.org/10.1007/978-3-030-11674-3_5 
estate booms accompanied by credit booms. These can vary greatly between countries. In the short run, there can be strong positive feedbacks via consumption, where down-payment constraints are loose, access to home equity loans is easy and rates of owner occupation are high. The UK and the US offer a sharp contrast here to Germany and France. Another feedback is via residential investment, which boosts employment and household income. In the UK, where the housing supply elasticity is low, such a feedback would be weaker than in the US, Ireland or Spain. There can also be pronounced macroeconomic effects of an overshooting of house prices induced by a series of strong positive shocks and amplified by extrapolative expectations of capital gains. This is so particularly in economies where high levels of leverage are possible, such as the UK and US (but not Germany or France), since leverage amplifies returns and risks. As Geanakoplos (2009) has argued, an endogenous leverage cycle can simultaneously drive growth in debt and in asset prices.

One rapid stabilising feedback loop, in countries where down-payment constraints are strong, is in the higher saving for a housing down-payment of those hoping to enter the housing market. Other negative feedbacks, such as the higher burden of debt on spending or of an expanded housing supply on house prices, would be stabilising if they acted quickly enough. They could, however, make a crisis still worse if they coincided with the above amplifying mechanisms deepening a downturn in housing and credit markets.

This discussion makes it clear that empirical evidence on variations between countries and over time, for example on the response of aggregate consumption to house prices, on the importance of extrapolative expectations in amplifying house price dynamics, and on differences in housing supply elasticities can be very helpful in assessing risks to financial stability. Understanding what drives house prices is important. In many countries, house price movements in major cities such as the capital are more extreme and often seem to lead the rest of the country. A framework for analysing prices at a regional level is therefore useful and Sect. 2 sets out a simple one: a two-region version in which the capital city is one, and the rest of the country the other. The example of London is used to illustrate the leading role of London house prices and the apparent ripple effect seen in the other regions. These make one suspect that early indications of overvaluation might be seen first in the London market. The special role of wealthy international investors in the top end of the market is a major issue for many world cities and London is no exception. Section 3 examines house prices in Paris vs France and summarises some empirical findings. Section 4 draws brief conclusions.

\footnotetext{
${ }^{1}$ Evidence, see Duca et al. (2016), is consistent with an asymmetry, a stronger response in a downturn - a credit crunch due to bad loans arising from negative housing equity-than in the upswing of the cycle.
} 


\section{A Framework for Regional House Price Modelling: The Case of London}

We begin by illustrating general issues of supply and demand with a simple log-linear 2-region model. Consider a two region economy $(j=1,2)$ with log-linear housing demands. One can think of region 1 being the capital city and region 2 the rest of the country. Because households have migration and commuting options affecting their location decisions, the demand for housing in region $\mathrm{j}$ depends not only on house prices at $\mathrm{j}$ but also on the relative price vis-à-vis the other region $r(j \neq r)$. Let $h$ be the log housing stock per head, $y$ be log real income per head, ph be the log real house price index and $\mathrm{z}$ be a demand shifter capturing other influences. Then the log-linear demand function at location $\mathrm{j}$ is:

$$
h_{j t}=-\alpha_{j} p h_{j t}-\alpha_{j r}\left(p h_{j t}-p h_{r t}\right)+\beta_{j} y_{j t}+\beta_{j r} y_{r t}+z_{j t}
$$

Note that relative house prices in regions $\mathrm{j}$ and $\mathrm{r}$ influence demand in region $\mathrm{j}$, as does income in region $r$ as well as in region $\mathrm{j}$. Reversing subscripts $r$ and $j$ gives the corresponding housing demand function in region $\mathrm{r}$. Solving the two equations for $p h_{j t}$ and $p h_{r t}$ as a function of incomes, housing stocks and demand shifters in the two regions, defines the inverse demand functions. ${ }^{2}$ These answer the question: given housing stocks, incomes and other influences in the two regions, what house prices will equilibrate demand and supply? Partial adjustment dynamics around these longrun solutions will generate equations suitable for estimation. Demand shifters in $z_{j t}$ should include credit conditions, interest rates, user cost and demography, not necessarily confined to region $\mathrm{j}$ : for example, relative expected appreciation dependent on lagged house price dynamics affects regional migration, see Cameron and Muellbauer (1998), Cameron et al. (2006a), and is part of regional house price dynamics in the UK, Cameron et al. (2006b).

An alternative formulation has the same long-run solution but allows a lagged, rather than instantaneous, response to relative house prices:

$$
h_{j t}=-\alpha_{j} p h_{j t}-\alpha_{j r}\left(p h_{j t-1}-p h_{r t-1}\right)+\beta_{j} y_{j t}+\beta_{j r} y_{r t}+z_{j t}
$$

These equations can be generalised to more than two regions. The strengths of the spill-over effects $\alpha_{j r}$ and $\beta_{j r}$ are likely to be greater for contiguous locations and for pairs of locations otherwise economically connected. To reduce the complexity of such models, apart from selecting a small number of strategic alternative locations, national average data can be used to summarise the remainder of alternative locations.

\footnotetext{
${ }^{2}$ See Deaton and Muellbauer (1980), pp. 56-57 and Theil (1976) on inverse demand functions and, for an empirical application, Barten and Bettendorf (1989). For simplicity, (5.1) omits the demand shifter in region $\mathrm{r}$.
} 
Solving for $p h_{j t}$, Eq. (5.2) implies a positive coefficient on $p h_{r t-1}$ because of the lagged effect of substitution. However, it is unclear whether, once incorporated in a dynamic adjustment process, this sign will be preserved in the equilibrium correction form of the equation for the change in $p h_{j t}\left(\Delta p h_{j t}\right)$. The reason is that excess demand in one region can spill over into the other(s). In other words, $\Delta p h_{j t}$ may increase not just with excess demand in region $j$ but also with excess demand in region $r$. If excess demand is represented by the deviation between fundamentals and respectively $p h_{j t-1}$ and $p h_{r t-1}, \Delta p h_{j t}$ would depend negatively on lagged house prices in both locations. This could overwhelm the effect of lagged substitution, leaving the overall sign ambiguous.

Such formulations give content to the spatial correlations often picked up in equation residuals. Some studies use complex estimation methods to 'correct' models developed for single locations-'islands'-for spatial correlations that reflect omitted variables arising from the spill-over effects discussed above, e.g. Oikarinen et al. (2018). US studies of metro areas adopting the 'islands' view include Hwang and Quigley (2006) and Follain and Velz (1995); Abraham and Hendershott (1996), Malpezzi (1996), Capozza et al. (2004) and Green et al. (2005) examine equilibrium correcting behaviour of house prices in MAs. The most influential recent study is Glaeser et al. (2008).

One area in the literature where spatial coefficient heterogeneity has been seriously considered in modelling the dynamics of regional house price change, is in the so-called ripple effect, where a leading location, experiences house price changes ahead of other regions. UK studies, where the leadership of London ahead of other regions has been evident for some time, include Meen (1999), Cook (2003, 2012) and Cook and Watson (2015). US studies include Gupta and Miller (2010, 2012), Holmes et al. (2011), Barros et al. (2012), and Chiang and Tsai (2016). Teye et al. (2017) find ripple effects from Amsterdam.

Cameron et al. (2006b) follow the theoretical framework set out in Eq. (5.1) above to incorporate between-region spill-overs between London and seven other UK regions using annual data from 1972 to 2003 . The house price equations control for mortgage credit conditions and for expectations of house price appreciation from reduced form forecasting equations incorporating data of which households are likely to have been aware. Credit conditions influence house prices directly but also indirectly by shifting more weight onto real interest rates and less on nominal interest rates as credit conditions ease. Regional heterogeneity includes a response of London given its role as financial centre (and to a lesser extent the South East region around London), but not other regions, to the stock market. But the effect is asymmetric, probably because negative stock market returns make relative returns in housing look better. Downside risk in housing induces another asymmetric response, namely to past changes in house prices: prospective home-buyers appear to have a memory of up to 4 years for negative returns in housing. This delayed the recovery of house prices after the crisis of the early 1990s, which was triggered by interest rate rises. Negative returns were particularly pronounced in interest-sensitive London. London also responds more strongly to shocks in income and interest rates than other regions. 
London is the only region not influenced by lagged house price changes in other regions. Regions near London are strongly affected directly by the London spill-over effect; regions further away, are influenced by spill-over effects from nearby regions, and hence indirectly by London. There is thus a clear picture of a ripple effect spreading out from London. National shocks from the stock market, interest rates and income and population growth, including growth in the adult population aged under 40, drive London and eventually feed through to other regions, together with the direct regional impact of interest rates, incomes, housing stocks, demography and population. The results suggest that, since 1997, mortgage credit liberalization, lower interest rates and financial sector leadership via London have been important factors increasing real house prices. Higher per capita income growth and population growth, driven by net foreign immigration, contributed to a rise since 1997 in house prices in Greater London compared to other regions.

With data up to 2003, Cameron et al. (2006b) found no signs of overvaluation in UK regional house prices, provided fundamentals of income, interest rates, credit conditions and lack of housing supply remained broadly within range. Short-term dynamics did not point to significant extrapolative over-shoots of house price expectations. Subsequently, as the Turner (2009) report for the Financial Stability Authority showed, lending became more risky, especially after 2005. For example, low-documentation loans accounted for about half of new mortgages in 2006-2007 and lenders increasingly resorted to money markets to fund short-term, incurring serious maturity mismatch. When the global financial crisis hit, unprecedented monetary policy easing, bank rescues and increased help for borrowers with payment difficulties were needed to stabilize the financial system.

Post-sample, the model helps to explain why, given the sharp falls in interest rates in the global financial crisis, London has outperformed other regions. However, it seems likely that a more explicit treatment of global investment in the top end of the London market would be needed to fully account for London's outperformance in the UK. Badarinza and Ramadorai (2018) have found evidence of safe-haven demand for London property, linked with foreign political and economic crises.

Figure 5.1 shows logs of the real UK house price index excluding London, the index for Greater London and for prime Central London. Since 1970, house prices in Greater London have outpaced house prices in the UK excluding London by a large margin, and particularly since 1997 as noted above. The UK's local property taxes are probably another factor in London's outperformance: uniquely in the OECD, they are highly regressive and based on valuations unchanged since 1991, with zero marginal tax rates on expensive properties disproportionately found in London. Since 1976, when the prime Central London data begin, this market has outpaced the Greater London market. However, this is not so taking 1985 as the base. After the global financial crisis, prime Central London prices recovered more rapidly than Greater London. This is probably due to low interest rates, foreign demand and lower sensitivity to credit constraints, which were relaxed only gradually after around 2012.

Granger causality tests for quarterly changes in log real house price indices suggest that Greater London helps significantly in explaining UK ex. London, but 


\section{5}

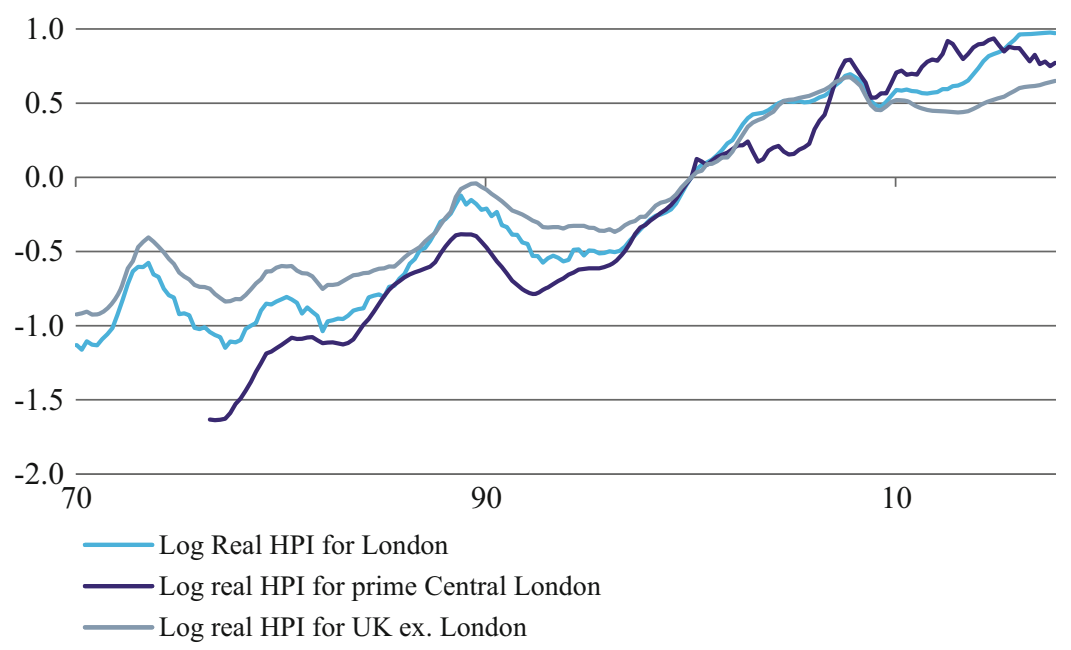

Sources: ONS (2018) HPI data base for UK and Greater London; prime Central London from 2000Q1, average of index for flats and houses from Property Vision, including data from Lonres (2018), spliced to the Knight-Frank (2018) index for prime central London for earlier years

Fig. 5.1 Log real house price indices for the UK excluding Greater London, for Greater London and for prime Central London

prime central London does not. In turn, both UK ex. London and prime central London help explain Greater London, but neither Greater London nor UK ex. help explain prime central London. Such tests have limited usefulness, but hint at substantial drivers of the prime central London market unconnected with macroeconomic conditions in the UK. The downturn in prime central London prices since 2015 is probably connected with sharp rises in Stamp Duty on property transfers and with attempts to clamp down on corporate vehicles previously used to evade such taxes. The latest data show the first annual decline in nominal house prices in greater London since 2009.

As far as risk factors for future house prices are concerned, higher interest rates are the most obvious, especially for London, which is more sensitive to interest rates than the rest of the country. The high levels of UK household debt relative to income and the negative feedbacks on consumer demand of lower house prices make the UK especially vulnerable, and is, of course, a reason for caution by the Bank of England in raising rates. It is also worth mentioning political economy as a risk factor. Unaffordable housing is a major part of the distributional conflict between those born after about 1980 and earlier cohorts. Higher student debt burdens, worse labour market prospects since 2007, higher levels of government debt and the burdens on government finances of an increasing aged population have added to the problems faced by post- 1980 cohorts. Reforms of property taxes and property rights of landowners, which disproportionately favour landowners and wealthy older 
generations, are increasingly seen as desirable to restore some degree of generational justice; see Corlett and Gardiner (2018) and Muellbauer (2018b). These must diminish prospects for UK house prices.

\section{The Case of Paris}

Chauvin and Muellbauer (2018) estimate a model for house prices in France as part of a 6-equation system also including aggregate consumption, the stock of housing loans, liquid assets, consumer credit and permanent income. The data are quarterly spanning 1981-2016. The theory background for the aggregate house price equation is an inverse demand function, where real house prices, rph, are determined by household demand, conditional on the lagged housing stock:

$$
\begin{aligned}
& \ln r p h_{t}=h_{0 t}+h_{1 t} \ln n m r_{t}+h_{2 t} \ln \text { user }_{t}+h_{3}\left(\ln \left(y_{t} / h s_{t-1}\right)+h_{4 t} E_{t} \ln \left(y_{t}^{f} / y_{t}\right)\right) \\
& \quad+h_{5} \text { demog }_{t}+h_{6} L A_{t-1} / y_{t}+h_{7} I F A_{t-1} / y_{t}+h_{8} \text { spillover }_{t-1}+h_{9} \text { trans }_{t}
\end{aligned}
$$

Here $h_{0 t}$ should increase with mortgage credit conditions, estimated as a latent variable common to consumption, housing loans and house price equations. The nominal mortgage rate is $n m r$, and user cost measuring interest rates minus expected appreciation is user. The parameter $h_{3}$ measures minus the inverse of the price elasticity of demand for housing, and is attached to the log ratio of income to the housing stock, which imposes the constraint that the income elasticity of demand for housing is one. The coefficient $h_{4 t}$ captures the relative effect of permanent to current income, analogously to a similar term in the consumption function. The remaining terms respectively represent the effects of demography, liquid and illiquid financial assets, spill-over effects from other countries' housing markets and transactions costs. Liquid and illiquid financial assets proved insignificant and international spill-overs are of modest quantitative importance. The remaining parameters are highly significant and $h_{3}$ is estimated to be close to 2 , implying a price elasticity of demand for housing of about -0.5 . Without mortgage credit conditions and demography, it is impossible to find stable and coherent parameter estimates for the 1981-2016 period.

Figure 5.2 shows the log real house price indices for Paris and France. The relative price for Paris fell in the 1970s, rose in the 1980s, fell in the first half of the 1990s, and rose since the financial crisis. The 6-equation model in Chauvin and Muellbauer (2018) was extended by including a seventh equation for log real house prices in Paris incorporating the common latent credit conditions measure. Given data limitations, income and housing stock data ${ }^{3}$ for the region around Paris, Île-deFrance, to which the capital is closely linked with an extensive rail network, were

\footnotetext{
${ }^{3}$ Even so, data before 1991 are sparse with regional GDP data used to extrapolate household income data back and dummies used to pick up possible deviations between the regional and national housing stocks.
} 


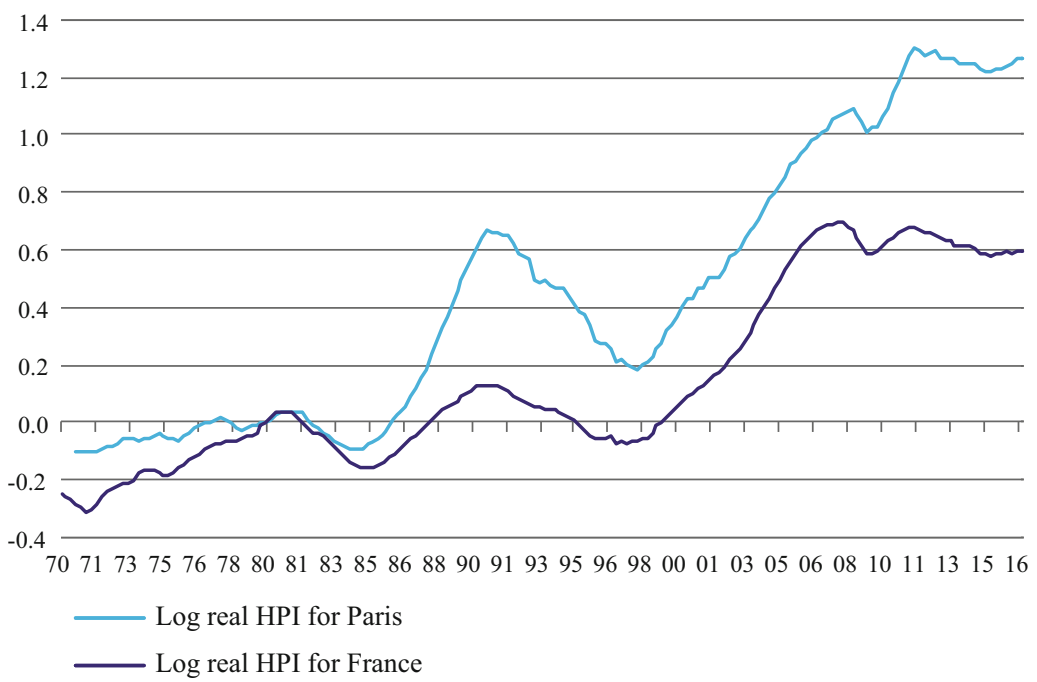

Source: OECD (2018) house price database for nominal house price index for France; INSEE (2018) for Paris price index for apartments, spliced in 1992 to Paris index from Friggit (2010). Both are deflated by the national accounts consumption deflator

Fig. 5.2 Log real house price indices for Paris and France

used for the Paris equation. The results can be summarised as follows: first, as for France, it is possible to accept the hypothesis of an income elasticity of one in the demand for housing, and liquid and illiquid assets are also insignificant. Second, regarding income per house, only that in Île-de-France matters in the long-run for Paris real house prices, with income per house in France being irrelevant. Third, nominal mortgage rates, mortgage credit conditions and a measure of risk all have substantially larger effects in Paris than they do for France. These results are consistent with higher levels of gearing needed to buy a house in Paris. Fourth, the coefficient on the lagged relative price of Paris to France is insignificant: as the discussion in Sect. 2 suggested, the sign is ambiguous since a substitution effect offsets a regional demand spill-over effect.

There are, however, major differences in short-term dynamics. The dynamic spillover between Paris and France, measured by a weighted average of lagged 1 and 4 year rates of appreciation in Paris minus appreciation in France, is very significant. It captures a relative momentum or expectations effect: demand for Paris homes is higher if recent appreciation in Paris exceeds that in competing locations in France. An international spill-over goes in the opposite direction: it is measured as a weighted average of appreciation in the eight countries whose citizens are most represented in purchases of housing in France, minus appreciation in France. The interpretation is that citizens in those countries are able to invest some of their domestic housing gains in France, and Paris in particular. After monetary union, the size of this spill-over effect is higher. 
To return to issues of financial stability, it is useful to consider the consumption estimates in Chauvin and Muellbauer (2018) for France during the house price boom between 1996 and 2008. These estimates suggest that the positive effects on consumption of higher housing wealth relative to income-a small but positive housing wealth effect- , and looser mortgage credit conditions, were largely offset by the negative effect of higher house prices and higher debt relative to income. France is therefore very different from the Anglo-Saxon economies where home equity loans produced large collateral effects of housing wealth on consumption. As a result, despite higher house prices, France did not experience an Anglo-Saxonstyle consumption boom in which ${ }^{4}$ the financial accelerator via home equity loans proved powerful and destabilising. Moreover, the induced increase in household debt will weigh negatively on future consumption.

The scale of extrapolative expectations in France is moderate. In Paris, it is also moderate, though there is also the momentum effect noted above by which recent appreciation in Paris relative to France feeds further appreciation. This can cause some overshooting of Paris prices and probably contributed to the subsequent greater decline in Paris home prices after 1991. In turn, this is likely to have been one factor in the rise in the proportion of non-performing bank loans in the mid-1990s, which is strongly correlated with mortgage credit conditions estimated by Chauvin and Muellbauer.

As is the case for France, the main potential downside risks in Paris come from higher interest rates, a renewed credit crunch and a downturn in real incomes given the background of a high level of French household debt relative to income. Of these, higher interest rates is the most relevant. If rates were to rise, and home prices fell, the rise in user cost would add to the downward pressure. The consumption equation for France, discussed in Chauvin and Muellbauer (2018), shows a substantial negative effect from real interest rates on housing and consumer loans, conditional on permanent and current income. Moreover, the estimated equation for permanent household income also shows a negative real interest rate effect, implying that aggregate demand in France is sensitive to higher real interest rates. Still, the absence of the amplifying feedback effect from house prices onto consumption, as found in the US and the UK, does limit the downside risks for France.

\section{Conclusions}

The evidence from the UK and France is that house prices in capital cities are more sensitive to interest rates and credit conditions. The upper ends of those capital city markets are also affected by international investment flows, which can create affordability problems for local residents and can divert residential construction

\footnotetext{
${ }^{4}$ As noted in Hendry and Muellbauer (2018), such effects were omitted in models, e.g. at the Bank of England and at the Federal Reserve.
} 
away from homes for middle-income households. A decade of ultra-low interest rates has contributed to driving house prices in many OECD countries to levels exceeding the peaks reached before the global financial crisis. In many countries this has exacerbated generational divides, with the UK offering one of the most extreme examples. It seems probable that these divides have contributed to the rise of populism. After a period of deleveraging, household debt to income ratios have again risen strongly in many OECD countries. The road to 'normalisation' of interest rates remains a rocky one.

\section{References}

Abraham, J. M., \& Hendershott, P. H. (1996). Bubbles in metropolitan housing markets. Journal of Housing Research, 7(2), 191-207.

Badarinza, C., \& Ramadorai, T. (2018). Home away from home? Foreign demand and London house prices. Journal of Financial Economics, 130(3), 532-555.

Barros, C. P., Gil-Alana, L. A., \& Payne, J. E. (2012). Comovements among U.S. state housing prices: Evidence from fractional cointegration. Economic Modelling, 29(3), 936-942.

Barten, A. P., \& Bettendorf, L. J. (1989). Price formation of fish: An application of an inverse demand system. European Economic Review, 33, 1509-1525.

Cameron, G., \& Muellbauer, J. (1998). The housing market and regional commuting and migration choices. Scottish Journal of Political Economy, 54, 420-446.

Cameron, G., Muellbauer, J., \& Murphy, A. (2006a). Housing market dynamics and regional migration in Britain (discussion paper 5832). Centre for Economic Policy Research.

Cameron, G., Muellbauer, J., \& Murphy, A. (2006b). Was there a British house price bubble? Evidence from a regional panel (discussion paper 5619). Centre for Economic Policy Research.

Capozza, D. R., Hendershott, P. H., \& Mack, C. (2004). An anatomy of price dynamics in illiquid markets: Analysis and evidence from local housing markets. Real Estate Economics, 32(1), 1-32.

Cerutti, E., Dagher, J., \& Dell'Ariccia, G. (2017). Housing finance and real estate booms: A crosscountry perspective. Journal of Housing Finance, 38, 1-13.

Chauvin, V., \& Muellbauer, J. (2018). Consumption, household portfolios, and the housing market in France. Economie et Statistique/Economics and Statistics (forthcoming).

Chiang, M.-C., \& Tsai, I.-C. (2016). Ripple effect and contagious effect in the US regional housing markets. Annals of Regional Science, 56(1), 55-82.

Cook, S. (2003). The convergence of regional house prices in the UK. Urban Studies, 40(11), $2285-2294$.

Cook, S. (2012). $\beta$-convergence and the cyclical dynamics of UK regional house prices. Urban Studies, 49(1), 203-218.

Cook, S., \& Watson, D. (2015). A new perspective on the ripple effect in the UK housing market: Comovement, cyclical subsamples and alternative indices. Urban Studies, 53(14), 3048-3062.

Corlett, A., \& Gardiner, L. (2018, March). Home affairs: Options for reforming property taxation. Resolution Foundation, Intergenerational Commission, pp. 1-66. https://www. resolutionfoundation.org/app/uploads/2018/03/Council-tax-IC.pdf

Deaton, A., \& Muellbauer, J. (1980). Economics and consumer behaviour. Cambridge: Cambridge University Press.

Duca, J. V., Muellbauer, J., \& Murphy, A. (2016). How mortgage finance reform could affect housing. American Economic Review, 106(5), 620-624. 
Follain, J. R., \& Velz, O. T. (1995). Incorporating the number of existing home sales into a structural model of the market for owner-occupied housing. Journal of Housing Economics, 4(2), 93-117.

Friggit, J. (2010). Le prix des logements sur le long terme, Conseil General de l'Environnement et du Développement Durable downloadable on http://www.cgedd.developpement-durable.gouv. fr/rubrique.php3?id_rubrique $=138$

Geanakoplos, J. (2009). The leverage cycle. In NBER macroeconomics annual 2009 (Vol. 24, pp. 1-65). Chicago: University of Chicago Press.

Glaeser, E., Gyourko, J., \& Saiz, A. (2008). Housing supply and housing bubbles. Journal of Urban Economics, 64(2), 198-217.

Green, R. K., Malpezzi, S., \& Mayo, S. K. (2005). Metropolitan-specific estimates of the price elasticity of supply of housing, and their sources. American Economic Review, 95(2), 334-339.

Gupta, R., \& Miller, S. M. (2010). 'Ripple Effects' and forecasting home prices in Los Angeles, Las Vegas, and phoenix. Annals of Regional Science, 48(3), 763-782.

Gupta, R., \& Miller, S. M. (2012). The time series properties of house prices: A case study of the Southern California market. Journal of Real Estate Finance and Economics, 44(3), 339-361.

Hendry, D. F., \& Muellbauer, J. N. J. (2018). The future of macroeconomic models: Macro theory and models at the Bank of England. Oxford Review of Economic Policy, 34(1/2), 287-328.

Holmes, M., Otero, J., \& Panagiotidis, T. (2011). Investigating regional house price convergence in the United States: Evidence from a pair-wise approach. Economic Modelling, 28(6), 2369-2376.

Hwang, M., \& Quigley, J. M. (2006). Economic fundamentals in local housing markets: Evidence from U.S. Metropolitan regions. Journal of Regional Science, 46(3), 425-453.

INSEE. (2018). Price index of second-hand dwellings - Paris - Flats. Accessed April 1, 2018, from https://www.insee.fr/en/statistiques/serie/010567012

Knight Frank. (2018). Prime London sales index - March 2018. Accessed April 1, 2018, from https:// www.knightfrank.com/research/prime-central-london-sales-index-march-2018-5389.aspx

Lonres. Accessed April 1, 2018, from https://www.lonres.com/

Malpezzi, S. (1996). Housing prices, externalities, and regulation in U.S. Metropolitan areas. Journal of Housing Research, 7(2), 209-241.

Meen, G. (1999). Regional house prices and the ripple effect: A new interpretation. Housing Studies, 14(6), 733-753.

Muellbauer, J. (2012). When is a housing market overheated enough to threaten stability?, RBA Annual Conference Volume. In A. Heath, F. Packer, \& C. Windsor (Eds.), Property markets and financial stability. Sydney: Reserve Bank of Australia.

Muellbauer, J. (2018a). The future of central banking: Festschrift in honour of Vítor Constãncio, May 2018. https://www.ecb.europa.eu/pub/pdf/other/ecb.futurecentralbankingcolloquium constancio201812.en.pdf

Muellbauer, J. (2018b, December). Housing, debt and the economy: A tale of two countries. National Institute Economic Review, 245, 20-33.

OECD. (2018). Residential Property Price Indicators (RPPIs) - Headline Indicators. Accessed April 1, 2018, from https://stats.oecd.org/Index.aspx?DataSetCode=HOUSE_PRICES

Office of National Statistics. (2018). House price index. Accessed April 1, 2018, from http:// landregistry.data.gov.uk/app/ukhpi

Oikarinen, E. S., Bourassa, C., Hoesli, M., \& Engblom, J. (2018). U.S. Metropolitan house price dynamics. https://www.aeaweb.org/conference/2018/preliminary/paper/kdr799FS 
Teye, A. L., Knoppel, M., de Haan, J., \& Elsinga, M. G. (2017). Amsterdam house price ripple effects in The Netherlands. Journal of European Real Estate Research, 10(3), 331-345.

Theil, H. (1976). Theory and measurement of consumer demand (Vol. II). Amsterdam: NorthHolland Publishing Company.

Turner, A. (2009, March). The Turner review: A regulatory response to the global banking crisis. Financial Services Authority.

Open Access This chapter is licensed under the terms of the Creative Commons Attribution 4.0 International License (http://creativecommons.org/licenses/by/4.0/), which permits use, sharing, adaptation, distribution and reproduction in any medium or format, as long as you give appropriate credit to the original author(s) and the source, provide a link to the Creative Commons licence and indicate if changes were made.

The images or other third party material in this chapter are included in the chapter's Creative Commons licence, unless indicated otherwise in a credit line to the material. If material is not included in the chapter's Creative Commons licence and your intended use is not permitted by statutory regulation or exceeds the permitted use, you will need to obtain permission directly from the copyright holder. 